\title{
Coblation cryptolysis for treatment of tonsillar stones: a randomized clinical study
}

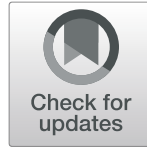

Osama A. Elsayad ${ }^{1 *}$ (D) and Mohammed S. Hussein²

\begin{abstract}
Background: Tonsillectomy is usually indicated in patients with tonsillar stones. It is thought coblation cryptolysis avoids the hazards related to monopolar bipolar diathermy and the regular cold surgical technique. This study compared the peri-operative outcomes in patients with tonsillar stones submitted to coblation cryptolysis, monopolar bipolar dissection, and cold dissection techniques. This randomized study included 105 patients with tonsillar stones. The included patients comprised three groups: $\mathrm{Gl}(n=35)$ was subjected to cold dissection, GII $(n=35)$ was subjected to monopolar bipolar diathermy tonsillectomy, and GIII ( $n=35)$ was subjected to coblation cryptolysis. Outcome parameters included operative time, intraoperative bleeding, consumption of postoperative analgesia, and time to normal food intake.

Results: GIII patients experienced significantly shorter operative time, less intraoperative bleeding, less consumption of postoperative analgesics, and less time to normal diet when compared with the other two groups.

Conclusion: Coblation cryptolysis is a safe and effective technique in the management of tonsillar stones. It appears to be superior to other surgical interventions.
\end{abstract}

Keywords: Tonsillar stone, Coblation cryptolysis, Diathermy tonsillectomy, Cold tonsillectomy

\section{Background}

Tonsillar stones are caused by pathological calcifications within the tonsillar crypts. The condition may present with chronic halitosis, dysphagia, cough, and ear pain and is usually treated by tonsillectomy [1]. While tonsillectomy is the most common surgery in the field of otolaryngology, the procedure is not without drawbacks and multiple surgical techniques and instruments have been developed to shorten operative time and reduce complication rate [2].

In this context, it was suggested that coblation tonsillectomy can provide quicker patients' recovery and a short hospitalization time [3]. The technique uses bipolar radiofrequency energy for soft tissue dissolution. It avoids trauma to pharyngeal muscles and related vessels

\footnotetext{
* Correspondence: drsayado@yahoo.com

'Department of Otolaryngology, Benha University Faculty of Medicine, Benha 13111, Egypt

Full list of author information is available at the end of the article
}

and improves wound healing [4]. The procedure became popular in the late 1980s because it caused less pain, had an easier recovery, and allowed greater retention of immune function [5].

The present study aimed to compare the peri-operative outcomes in patients with tonsillar stones submitted to coblation cryptolysis, monopolar bipolar dissection, and cold dissection techniques.

\section{Methods}

The present randomized study was conducted at a private hospital in Jeddah, Kingdom of Saudi Arabia. The study protocol was approved by the local ethical committee, and all patients gave informed consent before participation. The study included 105 adult patients with tonsillar stones indicated for tonsillectomy. Patients with bleeding disorder or contraindications to general anesthesia were excluded. The recruited patients comprised three groups: GI $(n=$
Springer Open (c) The Author(s). 2021 Open Access This article is licensed under a Creative Commons Attribution 4.0 International License, which permits use, sharing, adaptation, distribution and reproduction in any medium or format, as long as you give appropriate credit to the original author(s) and the source, provide a link to the Creative Commons licence, and indicate if changes were made. The images or other third party material in this article are included in the article's Creative Commons licence, unless indicated otherwise in a credit line to the material. If material is not included in the article's Creative Commons licence and your intended use is not permitted by statutory regulation or exceeds the permitted use, you will need to obtain permission directly from the copyright holder. To view a copy of this licence, visit http://creativecommons.org/licenses/by/4.0/. 

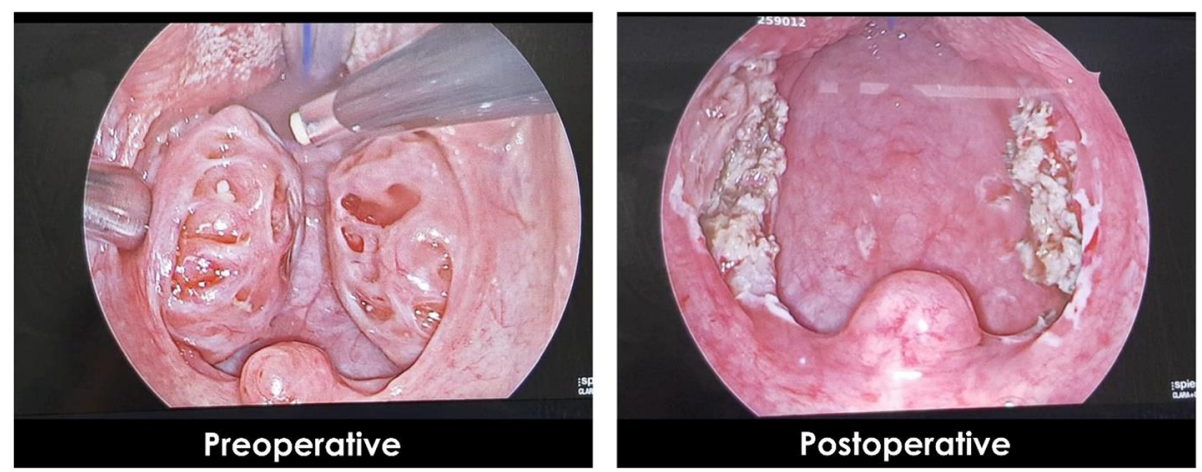

Fig. 1 Coblation cryptolysis

35) was subjected to cold dissection, GII $(n=35)$ was subjected to monopolar bipolar dissection, and GIII $(n=35)$ was subjected to coblation cryptolysis. Randomization was performed using computergenerated numbers and sealed envelope technique. Patient allocation was achieved by an independent researcher who was not aware of the nature of the study.

\subsection{Surgical technique}

All procedures were performed under general anesthesia through endotracheal intubation. Patients were positioned in the Rose position and a CrowDavis mouth gag was inserted. The tonsil was taken and mediatized with an Allis clamp. Cold dissection (CD) was performed using scissors to enter the superior peritonsillar space, and blunt dissection was used to remove the tonsil from the superior to the inferior pole. Hemostasis was performed by packing or suturing bleeding points with absorbable suture. In the monopolar bipolar dissection group, the incision was made with monopolar cautery at the anterior and superior parts of the anterior pillar. Dissection was performed at the peritonsillar cleavage plane with monopolar diathermy and bleeding points were coagulated with bipolar cautery. Coblation cryptolysis was made using coblation radiofrequency through a saline medium by cryptolysis through the crypts up to pharyngeal muscles (Fig. 1). Two electrodes were immersed in a medium of normal saline, which produces a plasma field of sodium

Table 1 Baseline characteristics of the studied groups

\begin{tabular}{lllll}
\hline & GI & GII & GIII & $P$ value \\
& $\boldsymbol{n}=\mathbf{3 5}$ & $\mathbf{n}=\mathbf{5 5}$ & \\
\hline Age (years) & $27.1 \pm 6.4$ & $28.5 \pm 7.5$ & $26.7 \pm 7.5$ & 0.62 \\
Male/female & $19 / 16$ & $16 / 19$ & $23 / 12$ & 0.24 \\
\hline
\end{tabular}

ions. Many highly ionized particles are contained in the plasma field resulting in coagulation of vessels and vaporization of tissues. In contrast to electrocautery, which works at a temperature of up to 400 ${ }^{\circ} \mathrm{C}$, coblation devices work at a temperature of $60{ }^{\circ} \mathrm{C}$ [3]. Irrigation and suction was employed at all times, and coagulation of vessels was done with the same instrument, Coblation ${ }^{\circ}$ which is a registered trademark of ArthroCare Corporation, Sunnyvale, CA, USA.

\subsection{Postoperative care}

Most patients were discharged the day after the surgical procedure. We prescribed paracetamol $1 \mathrm{~g}$ IV every $8 \mathrm{~h}$ in the day of admission and 3 tablets daily of paracetamol $(500 \mathrm{mg})+$ codeine $(8 \mathrm{mg})+$ caffeine $(30 \mathrm{mg})$ in subsequent days until pain subsided.

\subsection{Outcome parameters}

Outcome parameters included operative time, intraoperative bleeding, postoperative analgesics consumption, and time to normal food intake. Postoperative pain was assessed using the visual analogue scale (VAS) on a scale of $0-10$, with 0 representing no pain at all and 10 worst possible pain. When the pain level exceeds 3 , patients were given additional analgesics.

\subsection{Statistical analysis}

Results of the present study were presented as number and percent or mean and standard deviations. Numerical data were compared using $t$ test while categorical data

Table 2 Operative time in the studied groups

\begin{tabular}{lllll}
\hline & GI & GII & GIII & $P$ value \\
& $\boldsymbol{n = 3 5}$ & $\boldsymbol{n}=\mathbf{3 5}$ & $\boldsymbol{n}=\mathbf{3 5}$ & \\
\hline Operative time $(\mathrm{min})$ & $11.24 \pm 6.76$ & $10.76 \pm 5.95$ & $7.81 \pm 3.14$ & $<0.001$ \\
\hline
\end{tabular}


Table 3 Intraoperative bleeding in the studied groups

\begin{tabular}{|c|c|c|c|c|}
\hline & $\begin{array}{l}\mathrm{GI} \\
n=35\end{array}$ & $\begin{array}{l}\text { GII } \\
n=35\end{array}$ & $\begin{array}{l}\text { GIII } \\
n=35\end{array}$ & $P$ value \\
\hline Intraoperative bleeding (ml) & $57.4 \pm 27.99$ & $44.3 \pm 22.85$ & $11.8 \pm 6.14$ & $<0.001$ \\
\hline
\end{tabular}

were compared using the chi-square test. All statistical calculations were achieved using SPSS 25 (IBM, USA). P value less than 0.05 was considered statistically significant.

\section{Results}

The present study included 105 patients with tonsillar stones. They included three groups: GI $(n=35)$ was subjected to cold dissection of tonsillar stone, GII $(n=35)$ was subjected to monopolar bipolar diathermy tonsillectomy, and GIII ( $n=35)$ was subjected to coblation cryptolysis. All groups were matched regarding age and sex distribution (Table 1).

Comparison between the studied groups regarding the operative time showed significantly shorter intraoperative time in GIII (11.24 \pm 6.76 versus $10.76 \pm$ 5.95 and $7.81 \pm 3.14 \mathrm{~min}, P<0.001$ ) (Table 2). Also, GIII patients had significantly less intraoperative bleeding when compared to GI and GII (57.4 \pm 27.99 versus $44.3 \pm 22.85$ and $11.8 \pm 6.14 \mathrm{ml},<0.001$ ) (Table 3). Moreover, GIII patients experienced significantly less consumption of analgesics in the first postoperative 5 days (Table 4).

All patients achieved normal food intake within 15 postoperative days, but analysis implicated that coblation cryptolysis might be associated with fewer recovery days in comparison to the other two groups (Fig. 2).

\section{Discussion}

Coblation tonsillectomy has been proven safe and effective in previous studies and is widely used for tonsillectomy in both adults and children. In addition, coblation tonsillectomy is associated with better postoperative morbidity than are other techniques based on the postoperative pain and use of postoperative analgesia [6]. However, few studies compare coblation cryptolysis to $\mathrm{CD}$ and MBD in adults with tonsillar stones.

Results of the present study showed significantly shorter intraoperative time of coblation cryptolysis compared with the other two techniques in agreement with previous studies $[7,8]$.

Moreover, our study reported less intraoperative blood loss in coblation cryptolysis as compared to other procedures in line with the conclusions of [9] who concluded that in most patients submitted to coblation tonsillectomy, estimated blood loss was less than $32 \mathrm{ml}$ while in the cold dissection method, the estimated blood loss varied between 20 and $130 \mathrm{ml}$. Also, in the study of Timms and Temple [10] and Dwyer-Hemmings [11], the reported blood loss in coblation tonsillectomy was $19.10 \pm$ $8.6 \mathrm{ml}$ in comparison to $67.85 \pm 33.95 \mathrm{ml}$ in cold dissection.

In addition, our study noted significantly less postoperative analgesic consumption in the coblation group in comparison to the other two groups in harmony with the findings of Polites et al. [12] and Mudd et al. [13] who documented significantly less pain in coblation side during first 3 days postoperative as compared to the cold dissection method.

On the other hand, Philpott et al. [14] and Mitic et al. [9] found no significant differences between coblation and cold dissection regarding postoperative pain.

In our study, time to normal food intake was found to be shorter in coblation cryptolysis in agreement with Zhou

Table 4 Postoperative pain in the studied groups

\begin{tabular}{|c|c|c|c|c|c|}
\hline & Analgesics & $\begin{array}{l}\mathrm{Gl} \\
n=35\end{array}$ & $\begin{array}{l}\text { GII } \\
n=35\end{array}$ & $\begin{array}{l}\text { GIII } \\
n=35\end{array}$ & $P$ value \\
\hline \multirow[t]{3}{*}{ First 5 days } & Dexketoprofen & $14.6 \pm 1.8$ & $14.6 \pm 5$ & $8.8 \pm 2.3$ & $<0.001$ \\
\hline & Paracetamol + codeine & $14.6 \pm 3.7$ & $14.7 \pm 4.4$ & $9.1 \pm 2.4$ & $<0.001$ \\
\hline & Diclofenac Na ampoules & $4.3 \pm 1.8$ & $4.2 \pm 2.3$ & $2.1 \pm 1.7$ & $<0.001$ \\
\hline \multirow[t]{3}{*}{$5-10$ days } & Dexketoprofen & $10.7 \pm 5.2$ & $10.8 \pm 5.3$ & $7.9 \pm 4.1$ & $>0.05$ \\
\hline & Paracetamol + codeine & $12.6 \pm 6.5$ & $11.1 \pm 4.2$ & $9.0 \pm 2.3$ & $>0.05$ \\
\hline & Diclofenac Na ampoules & $3.4 \pm 3.7$ & $2.8 \pm 1.9$ & $2.4 \pm 1.7$ & $>0.05$ \\
\hline \multirow[t]{3}{*}{ 10-15 days } & Dexketoprofen & $8.7 \pm 4.2$ & $9.1 \pm 4.4$ & $7.3 \pm 3.3$ & $>0.05$ \\
\hline & Paracetamol + codeine & $9.3 \pm 4.5$ & $9.1 \pm 4.6$ & $7.5 \pm 3.2$ & $>0.05$ \\
\hline & Diclofenac Na ampoules & $2.4 \pm 2.8$ & $2.3 \pm 1.8$ & $1.8 \pm 1.6$ & $>0.05$ \\
\hline
\end{tabular}




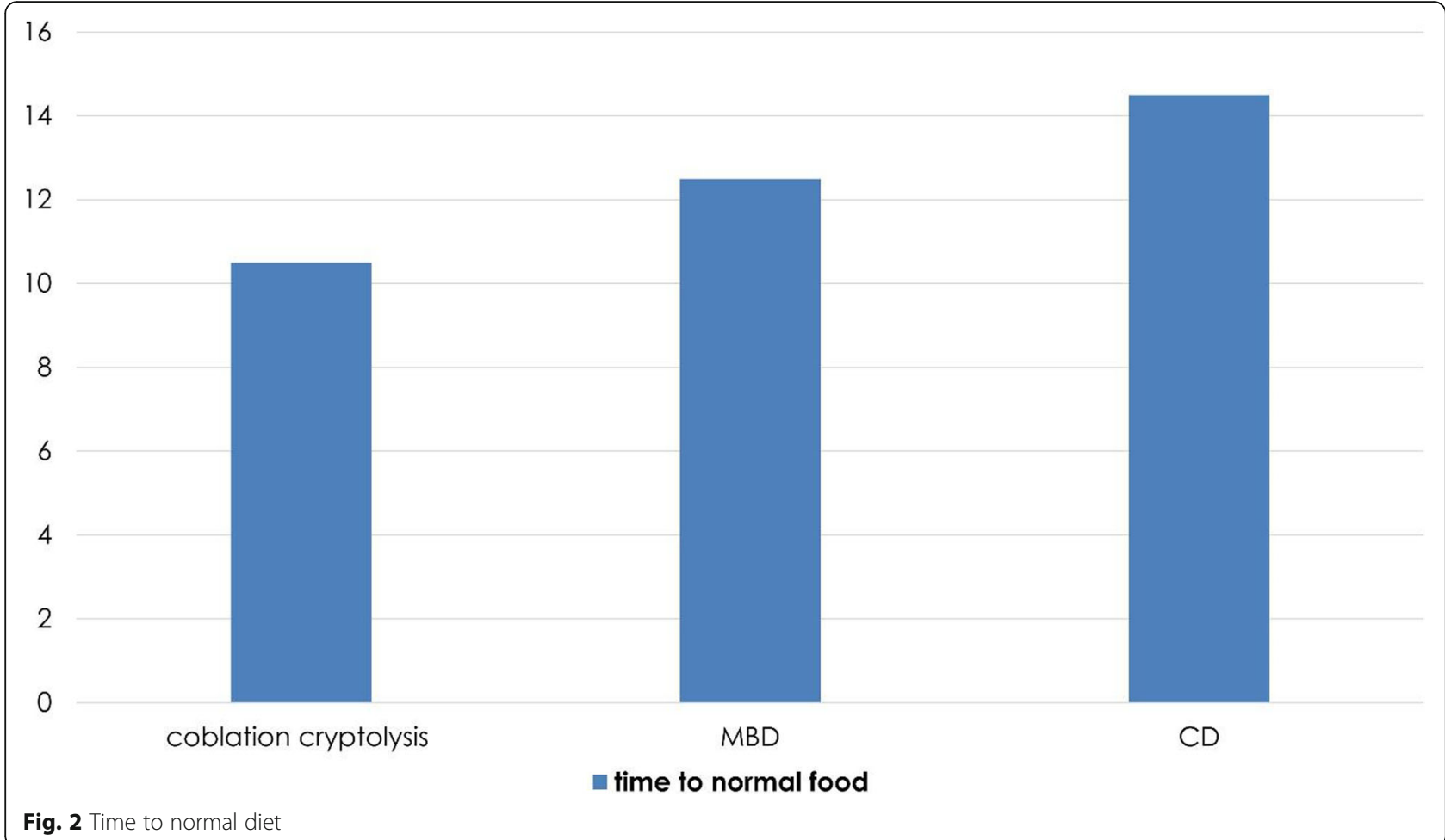

et al. [15]. They noted that coblation led to a 1.80-day reduction in the time required to return to normal food intake.

\section{Conclusion}

In conclusion, coblation cryptolysis is superior to the other two techniques. It was associated with shorter operative time, less intraoperative bleeding, less postoperative pain, and shorter time to normal food intake.

\section{Supplementary Information}

The online version contains supplementary material available at https://doi. org/10.1186/s43163-021-00106-9.

Additional file 1: Supplementary video. Video Demonstration of the Coblation Procedure. It can be found at the following link: https://youtu. be/rs_0iDma7XI.

\section{Acknowledgements}

Not applicable.

\section{Authors' contributions}

Conceptualization: $\mathrm{OE}$ and $\mathrm{MH}$; methodology: $\mathrm{OE}$ and $\mathrm{MH}$; formal analysis and investigation: $\mathrm{OE}$ and $\mathrm{MH}$; writing and original draft preparation: $\mathrm{OE}$ and $\mathrm{MH}$; writing, review, and editing: $\mathrm{OE}$ and $\mathrm{MH}$; resources: $\mathrm{OE}$ and $\mathrm{MH}$; supervision: $\mathrm{OE}$ and $\mathrm{MH}$. All authors read and approved the final manuscript.

\section{Funding}

None.

\section{Availability of data and materials}

The datasets during and/or analyzed during the current study are available from the corresponding author on reasonable request.

\section{Declarations}

Ethics approval and consent to participate

The study protocol was approved by the Ethical Committee of Saudi German Hospital, Kingdom of Saudi Arabia, on June 22, 2016, and all patients signed informed consent before participation.

\section{Consent for publication \\ Not applicable.}

\section{Competing interests}

The authors declare that they have no competing interests.

\section{Author details}

'Department of Otolaryngology, Benha University Faculty of Medicine, Benha 13111, Egypt. ' ${ }^{2}$ Department of Internal Medicine, Al-Azhar University Faculty of Medicine, Cairo 11754, Egypt.

Received: 3 November 2020 Accepted: 7 April 2021

Published online: 07 May 2021

\section{References}

1. Crameri M, Bassetti R, Werder P et al (2016) Tonsil calculi in the orthopantomography image. Swiss Dent J. 126(1):29-36

2. Kemal O (2012) Harmonic scalpel versus bipolar tonsillectomy: a doubleblind clinical trial. Eur Arch Otorhinolaryngol. 269(5):1533-1536 https://doi. org/10.1007/s00405-011-1872-8

3. Pynnonen M, Brinkmeier JV, Thorne MC, Chong LY, Burton MJ, Cochrane ENT Group (2017) Coblation versus other surgical techniques for tonsillectomy. Cochrane Database Syst Rev. 8:CD004619 https://doi.org/10.1 002/14651858.CD004619.pub3

4. Walner DL, Miller SP, Villines D, Bussell GS (2012) Coblation tonsillectomy in children: incidence of bleeding. Laryngoscope. 122(10):2330-2336 https:// doi.org/10.1002/lary.23526

5. Sathe N, Chinnadurai S, McPheeters M, Francis DO (2017) Comparative effectiveness of partial versus total tonsillectomy in children. Otolaryngol Head Neck Surg. 156(3):456-463 https://doi.org/10.1177/0194599816683916 
6. Lin C, Thung AK, Jatana KR, Cooper JN, Barron LC, Elmaraghy CA (2019) Impact of coblation versus electrocautery on acute post-operative outcomes in pediatric tonsillectomy. Laryngoscope Investig Otolaryngol. 4(1):154-159 https://doi.org/10.1002/lio2.212

7. Zainon $1 H$, Salim R, Daud MKM (2014) Coblation tonsillectomy versus dissection tonsillectomy: a comparison of intraoperative time, intraoperative blood loss and post-operative pain. Med J Malaysia. 69(2):74-78

8. Jayasinghe H, Williams A, Kerr AIG (2005) Randomised single blinded trial of outcome for coblation versus cold steel tonsillectomy. Emailed Presentation 2005:3404146

9. Mitic S, Tvinnereim M, Lie E et al (2007) A pilot randomized controlled trial of coblation tonsillectomy versus dissection tonsillectomy with bipolar diathermy haemostasis. Clin Otolaryngol. 32(4):261-267 https://doi.org/1 0.1111/j.1365-2273.2007.01468.x

10. Timms MS, Temple RH (2002) Coblation tonsillectomy: a double blind randomized controlled study. J Laryngol Otol. 116(6):450-452 https://doi. org/10.1258/0022215021911031

11. Dwyer-Hemmings $L$ (2018) 'A wicked operation'? Tonsillectomy in twentieth-century Britain. Med Hist. 62(2):217-241 https://doi.org/10.1017/ mdh.2018.5

12. Polites N, Joniau S, Wabnitz D, Fassina R, Smythe C, Varley P, Carney AS (2006) Postoperative pain following coblation tonsillectomy: randomized clinical trial. ANZ J Surg. 76(4):226-229 https://doi.org/10.1111/j.1445-2197.2 006.03700.x

13. Mudd PA, Thottathil P, Giordano T, Wetmore RF, Elden L, Jawad AF, Ahumada L, Gálvez JA (2017) Association between ibuprofen use and severity of surgically managed posttonsillectomy hemorrhage. JAMA Otolaryngol Head Neck Surg. 143(7):712-717 https://doi.org/10.1001/jama oto.2016.3839

14. Philpott CM, Wild DC, Mehta D, Daniel M, Banerjee AR (2005) A doubleblinded randomized controlled trial of coblation versus conventional dissection tonsillectomy on post-operative symptoms. Clin Otolaryngol. 30(2):143-148 https://doi.org/10.1111/j.1365-2273.2004.00953.x

15. Zhou X, Xu A, Zhen X, Gao K, Cui Z, Yue Z, Han J (2019) Coblation tonsillectomy versus coblation tonsillectomy with ties in adults. J Int Med Res. 47(10):4734-4742 https://doi.org/10.1177/0300060519867822

\section{Publisher's Note}

Springer Nature remains neutral with regard to jurisdictional claims in published maps and institutional affiliations.

\section{Submit your manuscript to a SpringerOpen ${ }^{\circ}$ journal and benefit from:}

- Convenient online submission

- Rigorous peer review

- Open access: articles freely available online

- High visibility within the field

- Retaining the copyright to your article

Submit your next manuscript at $\boldsymbol{\nabla}$ springeropen.com 